\title{
Anatomising the Problems of Nigeria: Is It Mainly Anchored on Weakness of State Institutions or Otherwise?
}

\author{
ARTHUR ELVIS CHUKWU ESQ \\ Head of Dept. Professional Ethics and Skills, Nigerian Law School Yola Campus
}

\begin{abstract}
The checkered history of Nigeria since her independence in 1960 is evidenced in the failures of successive governments to deliver requisite infrastructure that can lead to industrialization and a sustainable development with a strong economic base. This research work seeks to critically examine the assertion that the problem of Nigeria is mainly anchored on weakness of state institutions like the Police, the Armed Forces and the Civil Service. While agreeing that weak institution is a contributory factor to Nigeria's unfortunate status as a failed state, the research exposes and reveals myriads of other factors that have contributed in no small measure to the Nigerian problems. Military incursion into governance; leading to the enthronement of ethnicity and mediocrity; religious intolerance; rigged electoral processes; a constitutional frame work that abhors competition and adopts a feeding bottle approach to the constituent state within the federation who monthly rush to Abuja to share oil revenue; the mono economic base and lack of diversification; obsolete laws; lack of trust amongst ethnic groups; marginalization of some sections of the country; low regard for lives and properties; corruption; cultural differences; the roguish and unholy marriage called amalgamation of 1914; the colonial objective of exploitation and prospection of our natural resources; fear of domination by the North; the transfer of the apparatus of power to an unprepared North at the time of independence etc, appears to establish that our problems transcend weak institutions of state and is but a mere contributory factor. The scope of this research is limited to exposing these other factors as well as the weak institutions, and answers the question in the negative. Even as this work suffer from dearth of empirical evidence and materials, the doctrinal approach implicated in the interrogation of other contributory factors to the Nigerian problems using primary, secondary and tertiary sources reached the conclusion that even if strong institutions are developed, failure of government in the Nigerian state may still result from these other factors, and recommends that to solve the Nigerian problems, we must look beyond weak institutions.
\end{abstract}

Keywords: problems, amalgamation, corruption, ethnicity, laws, federation, development, war, population, INEC, census.

DOI: $10.7176 / \mathrm{JLPG} / 101-01$

Publication date:September $30^{\text {th }} 2020$

\subsection{Introduction}

The fundamental objective of any nation state must of necessity focus on the achievement and maintenance of peace, political, social and economic stability leading to the general welfare of the citizenry. Any country devoid of these essential attributes cannot lay claim to being a successful nation state. Nigeria has therefore continued to struggle to meet with these challenges since it became an independent nation on $1^{\text {st }}$ October, 1960 . Her recognition of this fact has found expression in the provisions of Constitution, the highest law of the land. ${ }^{1}$ Section 14 (2) (b) provides that "the security and welfare of the people shall be the primary purpose of government."

Our evolution as a nation state thus far, put us miles away from the attainment of these objectives to the extent that the indicators show us as a failed state. The Google Failed States Index for example, ranked Nigeria the $15^{\text {th }}$ most failed State in the world out of 177 nations surveyed. ${ }^{2}$ The ranking is predicated on applied indicators such as demographic pressures; massive movement of refuges and internally displaced people; legacy of vengeanceseeking group grievance; chronic and sustained human flight; uneven economic development along group lines and severe economic decline. ${ }^{3}$

First, we need to establish that there are problems in Nigeria; and second, we need to establish that these problems stem "mainly" from failed institutions of the state or, that there are many more other factors that have contributed to these problems other than failure of our state institutions.

\subsection{The Problems of Nigeria}

In tackling the first issue of whether there are problems in Nigeria, 1 want to be very clear that it is impossible to find any nation that does not have any problems at all. This is for example the reason for the existence of criminal law regimes in recognition that there must be crime in the society, but where the crime level assumes unimaginable proportions as to distort the civil society entirely, and query her value system, and the applicable laws seems to be

\footnotetext{
The Constitution of the Federal Republic of Nigeria 1999 as amended.

2 Failed State Index 2009, at https://www.proshareng.com. The newly released Failed State Index 2009 was published by a United States think-tank and an independent research organization- the Fund for Peace and the Magazine Foreign Policy. This is the $5^{\text {th }}$ edition since 2005. 3 Ibid
} 
ineffective in curbing the crime rate, then there is a problem. There may be natural disasters such as earthquake, hurricanes, flood etc, and yet nations develop environmental regulations to check them and match it with technological sophistication to prevent reoccurrence, and where there is already an occurrence, to have the ability for an immediate and efficient response system capable of reducing the extent of damage to lives and properties. Where a nation is not able to do this, then there is a problem. The above to my mind are manageable problems and not the type envisaged in concluding that Nigeria has problems. Ours are by far bigger problems and annoyingly, in most cases, man-made avoidable problems. Deeper than this, if we are able to justify the categorization of Nigeria as a failed state, then, we would have succeeded in establishing that there are problems in Nigeria.

The Oxford Advanced Learner's Dictionary of Current English" defines "problem" as "a thing that is difficult to deal with or to understand". It can also be defined as any question or matter involving doubt, uncertainty, or difficulty. ${ }^{2}$ Flowing from the above definition, Nigeria has myriads of problems but we shall try to discuss only a few of it for want of space and because it is also almost impossible to identify all the problems in Nigeria.

\subsection{Farmers-Fulani Herdsmen Conflict}

One need not go too far in Nigeria to observe demographic pressures resulting from drought, crop failure, the farmers-Fulani herdsmen conflicts that have resulted in sacking of communities and massive movement of refugees and internally displaced persons, civil disorders caused by ethnic, racial and religious conflicts, the dastardly killing of 2 catholic reverend fathers and 17 other parishioners in St. Ignatius Catholic Church Benue State by suspected armed Fulani herdsmen on the Catholic Diocese of Makurdi, Benue State. Father Moses Iorapuu said in his statement to that effect that:

The Catholic Diocese of Makurdi, which is one of the largest Dioceses in Nigeria, has been active in providing relief materials including education and skills acquisition lessons. To go for the priests means total destruction of everything we stand for and believe in as a people. ${ }^{3}$

There has been palpable tension in Benue State particularly Makurdi. Irate youths have blocked streets and roundabouts preventing vehicular movements and making bonfires. Shops, markets, banks, schools and offices are closed for fear of being attacked. Northerners in the state are also seen moving in droves for fear of being attacked by the irate youths. There is total anarchy as the Acting Governor of Benue State, Mr. Benson Abounu put it,

"The Governor, myself (sic) and the entire people of the state are very sad because

I can put it now that Benue is under siege ... We have been attacked from all corners and this is unacceptable. What happened today is a calculated attack, well planned and executed ... They have taken their time, they hit their targets and they got what they desired to do." 4

The priests, reverend fathers Joseph Gor and Felix Tyolaha were holding the 5.30 morning-mass, and parishioners were still coming when sounds of rapid gunshots rented the air. The two (2) priests who were holding the mass and 17 other parishioners were gunned down in cold blood inside the church while many others sustained injuries including bullet wounds. After attacking the church, the invaders descended on the community and razed down over 60 houses, farmland, food barns, after carting away what the people had in their barns in Mbalom Village of Benue State. It is the believe of Benue people that this is a genocidal attempt to wipe the Tiv people from the face of the earth. The Benue people have argued that these are jihadists who now masquerade as herdsmen whose goal is to conquer Benue and Tiv people for resisting advance into the Middle-Belt and the Eastern part of Nigeria since 1804 and for rejecting Islam. ${ }^{5}$

The Miyetti Allah, a group representing the Fulani herdsmen, had claimed that the killings is as a result of the Anti Open Grazing Law enacted by the Benue State House of Assembly which they claim did not provide their cows alternative grazing lands before the enactment of the law. Over 300,000 persons have since been displaced internally from their homes since this attack started. It should be noted that the killing of the priests and parishioners took place barely 4 days after 10 persons were murdered by suspected herdsmen in neighboring Guma Local Government Area and about 300 houses destroyed by men suspected to be military personnel in Naka, GwerWest Local Government Area of Benue State. ${ }^{6}$ This prompted the President of the United States of America, Donald Trump to tell president Buhari of Nigeria that:

We have had very serious problems with Christians who are being murdered in Nigeria; we are going to be working on that problem very, very hard because

\footnotetext{
Sally, Whenmeier, M. Ashby, ed. Oxford Advanced Learner's Dictionary of Current English (New York: Oxford University press (2000) p. 298

English Dictionary, at http://www.dictionary.com, Retrieved June 18, 2018, 9.00am

Ibid. (n.p.)

4 Ibid. n.p

"Fresh Bloodbath in Benue, 2 Catholic Priests, 17 Others Killed by Herdsmen", at https://www.vanguardngr.com/2018/04/freshblood.....Retrieved June 17, 2018, 12.48 PM

6 Ibid. (n.p.)
} 
we cannot allow that to happen. ${ }^{1}$

\subsection{Insecurity}

The location of several Internally Displaced Persons (IDP's) camps littered across the country are clear indicators of chronic and sustained human flight as a result of these conflicts. The farmers-Fulani herdsmen conflict has assumed disgraceful proportions that there is hardly any day that passes without the media reporting of several killings by armed bandits. Suicide bombings have become more or less a way of life in Nigeria. The killings, maiming, rape, arson and kidnapping by the Boko Haram group ${ }^{2}$ has attracted global attention. About 276 school girls were abducted from their school in $\mathrm{Chibok}^{3}$ in 2014. The plea by the parents of the victims and several human rights organizations like the "Bring Back Our Girls Group" led by the former minister for education, Oby Ezekwesili, and even the wife of the former US President, Michelle Obama, fell on deaf ears. The former US first lady said "In these girls, Barack and I see our own daughters". ${ }^{4}$ It is pertinent to note that many of the abducted school girls are Christians who were forcefully converted to Islam. Boko Haram released a video showing the missing girls and alleging they had converted to Islam and would not be released until all militant prisoners were freed. ${ }^{5}$ As if enough was not enough, on the February19, 2018, by 5.30pm, Nigerians were again served another dish of the abduction of 110 innocent and defenseless girls from a government-owned secondary school in Dapchi, Yobe State of Nigeria. ${ }^{6}$ The believe is widely held that this particular abduction was stage-managed by the Buhari administration to score cheap political point on the readiness of the regime to quick response in contradistinction to the Goodluck Jonathan ${ }^{7}$ administration's inability to release the Chibok girls. These spates of kidnappings have made parents particularly in the North-Eastern part of Nigeria to withdraw their female children from schools since they now appear obvious easy target. This has had tremendous impact on the girl-child education which by necessary implication has grave negative impact on the Nigerian society generally.

The arraignment of the suspected billionaire kidnapper, Chukwudumeme Onwuamadike also known as Evans, ${ }^{8}$ and several other kidnapping incident trials have yielded no positive result as the prevalence has reached alarming proportions leading to some States like Edo making it a capital offence. Nigeria has a big problem here.

\subsection{Corruption}

The word "corruption" lacks universally acceptable definition because different people perceive the word differently. From legal point of view, corruption is "the act of doing something with intent to give some advantage inconsistent with official duty and the rights of others." ${ }^{9}$ From economic standpoint, "corruption is rent seeking behavior by public officials through the exploitation of their monopoly discretionary powers." 10 Socially speaking, it is the violation of socially accepted norms of duty and welfare. ${ }^{11}$ Within the political space, corruption may be defined as the synthesis of the misfit between the private accumulation ideals of capitalism and the public welfare virtues of democracy. ${ }^{12}$ In spite of the available diverse definitions, "corruption is consensually agreed to involve

1 "Trump Warns Buhari Over Killing of Christians in Nigeria" https://www.google.com.ng retrieved June 17, 2018. This was in the meeting of the two presidents on Monday the $30^{\text {th }}$ April, 2018 at the Oval Office before the two leaders addressed a joint press conference. Also discussed in the meeting was the Nigerian security and economic problems among others.

2 This is a jihadist militant terrorist group based in north-eastern Nigeria founded in 2002 in Maiduguri the capital of Borno State by Mohammed Yusuf. This religious sect has leaders such as Abaubakar Shekau and Abu Musab al-Barnawi. Its activities are majorly on the northern part of Nigeria, Cameroon, Niger and Chad.

3 On the night of April 14, 2014, 276 female students were kidnapped from the Government Secondary School in the town of Chibok in Borno State Nigeria by Boko Haram whose negotiator, Shehu Sani, Stated that the group wanted to swap the abducted girls for its jailed members. Up till now, 113 of these Girls have not been returned to their parents. Some are alleged to have died while others are claimed to be forcefully married to Boko Haram members. Eventually, all the girls, according to the Federal Government of Nigeria, have been released after negotiations with the Boko Haram group, except one, a Christian girl among the abductees, miss Leah Sharibu.

4 “Michelle Obama's \#Bring Back our Girls Picture Sparks Criticism of American Drone Strikes", at https://www.washingtonpost.com>news, Retrieved June 17, 2018. See also First lady-Archived on Twitter, "Our prayers are with the missing Nigerian Girls and their families", at https://twitter.com>flotus44>status Retrieved June 17, 2018.

5 https://www.telegraph.co.uk>boko haram, Retrieved June 17, 2018.

${ }^{6}$ https://en.m.wikipedia.org>wiki>Dapchi, Retrieved June 17, 2018

7 "Dapchi Girls kidnapp June Release Was Staged to Swindle Nigerians". Governor of Ekiti State, Ayodele Fayose said the abduction and release of the school girls by Boko Haram insurgent group in Dapchi, Yobe State was a well-orchestrated plot to dupe and swindle Nigerians by the Federal Government. seehttps://www.saharareporters.com>2018/03/21>dapchi ,Retrieved June 17, 2018.

8 "Billionaire Kidnapper: Evans Files Fresh 1 1billion Suit Against Nigerian Police" at https://www.dailypost.ng>News Retrieved June 17, 2018. In a dramatic turn of events, the alleged billionaire kidnapper had sued the Nigerian Police seeking N1billion in damages over alleged unlawful sealing of his property in Lagos. The suit filed by his lawyer, Mr. Olukoya Ogungbeje, has the Nigeria Police, the Inspector General of Police, Intelligence Response Team, (IRT), ACP Abba Kyari and DSP Phillip Rieninwa as respondents. This is a clear indication of how police mishandle very important cases.

9 B.A.Garner, (Editor-in-chief), Black's Law Dictionary $8^{\text {th }}$ edn. (US; Thomson West, 2004), P. 371

10 I.F.I. Shihata, "Corruption -A General Review With an Emphasis on the Role of the World Bank" Dickinson Journal of International Law Vol. 15 (n.p),

11 Ibid.P. 456

12 J.Girling, Corruption, Capitalism and Democracy, (London: Routledge , 1997) Ch. 1 
the misuse of public power for private gain." ${ }^{11}$ It is therefore safer, for reasons of clarity, to adopt a narrow, enumerative definition of the conduct, which is, by specifying some corruption types such as bribery, trading in influence, embezzlement, extortion, fraud, favoritism, illegal political party financing, and abuse of discretion. ${ }^{2}$ Corruption is endemic in Nigeria when viewed from the angle of how widespread it is, the scale and the class of persons involved in the crime. It is also recognized as a category of economic and financial crime in Nigeria. ${ }^{3}$ Igbinedion S. A, put it succinctly as follows:

It pervades every stratum of public office and constitutes a means to the end of private enrichment at the expense of the common good. Noteworthy is the fact that public office is not merely a medium of illicit accumulation of public wealth; it constitutes the private estates of corrupt public officials who have routinised plunder of public wealth. ${ }^{4}$

The embezzlement or outright plunder of the Nigerian treasury by the former dictator and self-styled President of Nigeria, Ibrahim Babangida, still leaves a sour test in the mouth. Babangida and his cronies are believed to have misappropriated $\$ 12.2$ billion out of the $\$ 12.4$ billion in the Dedicated Account with the Central Bank of Nigeria $(\mathrm{CBN}){ }^{5}$

The late Nigerian dictator, General Sani Abacha, also corruptly took from the CBN between $\$ 2.3$ and $\$ 2.8$ billion. ${ }^{6}$ Till date, the government of Nigeria is still in search to recover this loot. It is interesting to note that the same ugly situations which were encapsulated in the broadcast by Sani Abacha heralding the Buhari military regime in December 31, 1983 became even worse during the Babangida and Abacha era. The wording of the broadcast interestingly says:

Fellow countrymen and women.(sic) I, Brigadier Sani Abacha, of the Nigerian army address you this morning on behalf of the Nigerian armed forces. You are all living witnesses to the great economic predicament and uncertainty, which an inept and corrupt leadership has imposed on our beloved nation for the past four years. I am referring to the harsh, intolerable conditions under which we are now living. Our economy has been hopelessly mismanaged. We have become a debtor and beggar nation. There is inadequacy of food at reasonable prices for our people who are now fed up with endless announcements of importation of foodstuffs. Health services are in shambles as our hospitals are reduced to mere consulting clinics without drugs, water and equipment. Our educational system is deteriorating at an alarming rate. Unemployment figures including the undergraduates have reached embarrassing and unacceptable proportions. In some states, workers are being owed salary arrears of eight to twelve months and in others there are threats of salary cuts. Yet our leaders revel in squandermania, corruption and indiscipline, and continue to proliferate public appointments in complete disregard of our stark economic realities... ${ }^{7}$

Interestingly, the above scenario which aptly captures the Nigerian situation then has not changed even now, in all respects. In fact, in some cases, it has become even worse. For example, the demonstration of the endemic nature of corruption in the country is, perhaps, manifested by the fact that, from 1996 to 2005, the CPI ${ }^{8}$ consistently perceived Nigeria to be in the category of the sixth most corrupt countries in the world. "The "Abacha loot" has entered the Nigerian lexicon of corruption and is estimated to be about \$16 billion. R. Baker summarized it in the following words:

The biggest single thief in the world in the 1990's was almost certainly the late military dictator, Sani Abacha, with $\$ 12$ billion to $\$ 16$ billion passing out of Nigeria in corrupt and tax evading money during his murderous five year

\footnotetext{
1 S.A. Igbinedion, "Enthroning Good Governance in Nigeria: The Challenge of Corruption", A Journal of Contemporary Legal Issues, Vol. 5, 2013.p. 145. See also P.J. Henning, "Public Corruption: A Comparative Analysis of International Corruption Conventions and United States Law", Arizona Journal of International and Comparative Law Vol. 18 (n.n.) 2001, p. 793 at 802-803.

2 Ibid. 145

3 S. 46 Economic and Financial Crimes Commission Act 2004.

${ }^{4}$ S.A. Igbinedion, Op.Cit, p. 147. See also D. Agedah, (ed.), Corruption and the Stability of the Third Republic (Lagos; Perception Communications), 1993 , pp. 35-39

${ }^{5}$ See P. Okigbo, Panel on the Reorganization and Reform of the Central Bank of Nigeria Report, Executive Summary 1994, p. 12 at https://dawodu.com/okigboreport I, htm . Retrieved June 18, 2018.

6 T. Mastand, et al; "The lost Billions: The Inside story of the Hunt-from Lagos to New York to Geneva-For an African Dictator's Stolen Loot", Newsweek, March 13, 2000, p.2.

${ }^{7}$ Max Siollun, Solders of Fortune, Nigerian Politics from Buhari to Bababgida 1983-1993, (Abuja: Nigeria, Cassava Republic Press, 2013), Appendix 1, p.276

${ }^{8}$ CPI, a product of Transparency International (TI), ranks almost 200 countries in terms of perceived levels of corruption, as determined by expert assessments and opinion surveys. See Transparency International, survey and Indices at https://www.archive.transparency.org/policy_research/surveys_indices/cpi. Retrieved June 19, 2018.

${ }_{9}^{9}$ S.A. Igbinedion, Op.Cit., p. 148, footnote 32
} 
regime, most of this to the personal accounts of Abacha and his immediate family members. ${ }^{I}$

Remember the \$214 million National Identity Card Scheme scam, the $\$ 17$ billion stolen by the former Inspector General of Police, Tafa Balogun, the $\$ 1.16$ billion by former Governor of Plateau State, Joshua Dariye who was only recently jailed for 14 years, after so many years; what about the N124 billion by the former Governor of Bayelsa State, late Diepreye Alamieyeseigha, the government of Olusegun obasanjo that allegedly spent $\$ 16$ billion to provide electricity for the country yet we are still in darkness and the beneficiaries of the loot live in luxury. ${ }^{2}$ Not to forget the persistent fuel subsidy scandal. ${ }^{3}$ According to the House of Representative Ad- hoc Committee on Fuel Subsidy Report, the difference between the $\$ 245$ billion appropriated for fuel subsidy in 2011 and the $\$ 1.3$ trillion actually paid to marketers largely represented plunder of national wealth. What of the humongous $\$ 273.9$ billion pension scheme scam between 2005-2011 only. Senator Aloysius Etok-led Senate Joint Committee on Public Service and Establishment and State and Local Government Administration, described it as "syndicated and institutionalized corruption, fraud and embezzlement in the management of pension funds in the country." 4

The very funny $\$ 270$ million IDP camp grass cutting scandal by the secretary to the Federal Government, Babachir Lawal, is still fresh in our memory. ${ }^{5}$ Sambo Dasuki is still languishing in jail for the \$2. 1 billion arms scandal. ${ }^{6}$ Nigeria's problem is better summarized, as no single research can exhaustively treat all our problems.

\subsection{Other Problems}

The health sector is not spared, with incessant strike action that has not changed the status of our hospitals from "mere consulting clinic" without drugs. The educational sector is not any better. The poverty level in the country is unimaginable and we have been labeled the "poverty capital of the world." Unemployment level has reached disgraceful all time high. Inflation rate is one of the highest globally. The list is endless and there appears to be no future for the teaming Nigerian youths. We appear to have squandered our tomorrow today. Militancy and civil unrest is the order of the day. Cries of marginalization and self-determination as fall outs of bad government policies aimed at keeping down certain sections of the country, our unsuccessful attempts at democracy with rigged electoral processes, religious intolerance, enthronement of mediocrity in place of meritocracy, the shameful uncertain census figures, bad government policies and visionless leadership, high crime rate, human rights abuses, child labor and trafficking, a steadily dwindling economy ,nepotism, tribalism, favoritism, civil war, Boko Haram menace, banditry, Fulani herds attacks, religious upheavals, lack of trust among the constituent ethnic groups, political instability, insincerity, lack of patriotism, bad governance, no identifiable good leaders, an almost zero international respect et al, are only some of our very many problems.

\subsection{Causes of the Problems}

Having sufficiently dealt with the problems existing within the Nigerian State, our next task will be to trace the root causes of these problems and to find out whether it is mainly anchored on the weakness of state institutions. In this respect, two key words call for analysis. That is "institution" and "weak".

The Oxford Advanced Learner's Dictionary" defines "institution" as "a large important organization that has a particular purpose". It could be described as agencies through which government works. It is an organization, establishment, foundation, society, or the like, devoted to the promotion of a particular cause or program, especially one of a public, educational, or charitable character. ${ }^{8}$

"Weak" means not physically strong. Easy to influence. Not having much power. That which people are not likely to believe or be persuaded by. ${ }^{9}$ A weak institution therefore will mean institutions that have become incapable of achieving the purpose for which it is set up.

\subsection{The Amalgamation}

Cultural differences between the constituent ethnic groups that make up Nigeria, the mistrust and divisiveness,

\footnotetext{
${ }^{1}$ R. Baker, "Money Laundering and Flight Capital: The Impact in Private Banking”, Senate Committee on Governmental Affairs, Permanent Subcommittee on Investigation Report November 10, 1999

${ }^{2}$ D. Elombah, "Olusegun Obasanjo Versus Ndudi Elumelu", at https://www.elombah.com/index.php?option=com_content $\$$ view= article $\$$ id= 803: Olusequn-obasanjo- versus-godwin- elumelu $\$$ catid= 52:daniel-elombah $\$$ itemid $=73$. Retrieved June 19, 2018, 5.30pm.

3 "To Verify and Determine the Actual Subsidy Requirements and Monitor the Implementation of the Subsidy Regime in Nigeria Resolution No. HR.1/2012" at https:/www.nigerianmuse.com/wp-content/uploads/2012/04/house-of-Reps-Report-on-Fuel-Subsidy-Probe-April2012/pdf. Retrieved June 19, 2018. 5.45pm.

${ }^{4}$ https://www.allafrica.com/stories.201206210904.html. Retrieved June 19, 2018, 6.03pm.

5 "Reps Cry Foul Over Use of $\$ 270 \mathrm{~m}$ to Clear Grass at IDP Camps-vanguard News" at https://www.vanguard.com Retrieved June 19, 2018, 6. $15 \mathrm{pm}$.

6 "Nigeria's Dasuki Arrested Over \$2 bn Arms Fraud", at https://www.bbc.com>w...

$6^{\text {th }}$ edition, p. 621

8 https://www.dictionary.com. Retrieved June 20, 2018, 9.20am

9 Op. Cit., p. 1350
} 
could not have been traceable to any weak institution. Nigeria as a federation is a product of British experiment in political cloning, having come into existence in 1914 by virtue of the amalgamation of the Northern and Southern protectorates of the country by Lord Lugard, the first Governor General. ${ }^{1}$ This union has created endless animosity between the two protectorates because none of them was prepared for it. The WILL has this to say of the amalgamation;

The ill conceived connubial resolution that brought Southern Nigeria and Northern Nigeria together in 1914 is up till today being debated as the basis of the problems we are facing as a nation... In retrospect, Southern Nigeria and Northern Nigeria were coalesced together in 1914 to form a single colony of Nigeria. The unification was consummated purely for economic reasons rather than political. It was a union marshaled and carried out without any form of consultation between the South and the North. History has it that, Northern Nigeria Protectorate had a budget deficit, and the colonial administration sought to use the budget surpluses in Southern Nigeria to offset the deficit of the Northern Nigeria... Despite the fact that the unification process developed embryonic problems and was greatly undermined by the persistence of different regional perspectives on governance between the Northern and Southern provinces, the colonial masters never deemed it fit to put up ameliorative process that could have made the forced marriage work... Today, many observers of our national polity are of the opinion that Nigeria's myriads of problems are as a result of the 1914 amalgamation. This is why, up till this moment, the relationship between the two is one based on mutual suspicion and is responsible for the country's retrogressive nature among comity of nations... It has always been a cat and mouse relationship in which every ethnic group tries to outsmart one another in an existential 'rat-race'.

Nothing can be clearer and more direct in the conclusion that our problems as a country are not mainly anchored on weak institutions. It has to be noted that at this stage of our historical evolution, not much has been established as institutions. At various stages of this matrimony, Nigeria has recorded series of events including a civil war and currently Boko Haram menace, banditry, Fulani herdsmen attacks, insurgency, religious upheavals, mistrust, etc. The amalgamation is morbidly reflecting in all our ways of life even as a sovereign nation. The taunted 'unity in diversity' is an illusion as constituent ethnic groups continue to champion their causes as tribalists rather than as nationalists. The question begging for answer is, how long do we continue to strive in deceit and treachery when we are all aware that the 'marriage' has brought us more loss than gain? "From the way the 1914 amalgamation was conceived, the union was never meant to be a political elixir but an ill-conceived palliative economic measure."3 It is safe to conclude that almost Nigeria's entire problem came post-amalgamation as Nigeria started existing after the inglorious amalgamation. Lord Lugard was criticized not only for basing his rule of Nigeria on a military system but also for running the country with half of each year spent in England, distant from realities of Africa and compelling his subordinates to delay decisions on many important matters until he returned. While Southern colonial administrators welcomed amalgamation as an opportunity for imperial expansion, their counterparts in the Northern Provence believed that it was injurious to the interest of the areas they administered because of their relative backwardness and that it was their duty to resist the advance of southern influences and culture into the north. Southerners, on the other hand, were not eager to embrace the extension of legislation originally meant for the north to the south.

Richard Aknjide (SAN) surmised his view of the amalgamation as a fraud. According to the learned Senior Advocate of Nigeria:

After Lugard created the protectorate of the Northern Nigeria, he sent dispatches to London in which he said the North is poor and they have no resources to run the protectorate in the North. That they have no access to the sea; that the South has resources and that they have educated people... Therefore because it was not the policy of the British Government to bring the tax-payers money to run the protectorate, it was in the interest of the British tax-payer that there should be amalgamation. What the British amalgamated was the administration of the North and the South. This is one of the root causes of the problems of Nigeria and the Nigerians. When the amalgamation took effect, the British Government sealed off the South from the North and allowed only minimal contact between them from 1914 to 1960, a period of 46 years because it was not in the British interest that the North be allowed to be 'polluted' by the educated South. That was the basis on which

\footnotetext{
1 S.A. Bello, "The Nigerian State and the Challenge of Divisionism and Dichotomy", Journal of Contemporary Legal and Allied Issues, Ife Juris Review, 2015, part 1, p. 277

${ }^{2}$ See "Opinion: Is 1914 Amalgamation a Blessing or a Curse?" at https://www.thewillnigeria.com, Retrieved June 20, 2018, 11. 23am

${ }^{3}$ Ibid.
} 
we got our independence in 1960 when I was in the parliament. ${ }^{1}$

This exposition by the learned Senior Advocate of Nigeria is particularly revealing and instructive as it exposes the very root cause of the Nigerian problem tracing it from the dispatches made to London by Lord Lugard. Perhaps, after reading this, you will completely agree that this is majorly our problem as a country, and we need to go back to the drawing board and decide whether we really need to continue together as a country. The conclusion of the learned icon was emphatic when he said:

"In fact, the so-called Nigeria created in 1914 was a complete fraud. It was created not in the interest of Nigeria or Nigerians but in the interest of the British." 2

Tracing our problem from 1914 and narrowing it to 1960, Bello was no less emphatic. According to him, ...the political history of the country since 1960 till now is characterized by corruption, nepotism, favoritism, bad governance (sic) tribalism, ethnic and religious upheavals, lack of trust, political instability, insincerity, lack of patriotism etc. As a result of all these, Nigeria as a country is yet to evolve into a nation and can be described more as a ship without anchor or to use the word of chief Obafemi Awolowo, a mere geographic expression".(sic) ${ }^{3}$

\subsection{Manipulated Census Figures}

Census figures are the basic ingredient upon which any meaningful economic planning can be based. Without a sincere census, there is hardly anything the best of any economic team can achieve in terms of good planning and adequate provision of infrastructure. How would a country conduct a free and fair election without it? How do we know the number of the aged people to cater for, or the number of the productive youth population? How can we even tackle the issue of unemployment or the provision of adequate electricity, or a good public health sector? In fact, almost everything you want to do in any economy is predicated on the population census figures. It is very disgraceful that till now the Nigerian population figure is a mere estimate, a gaze and an approximation. This is part of the reason for the dwindling economy with policy summersaults. At one time, our population was put to "about 120 million", at other times, it is said to be 150 million. It is now estimated at 180 million. The policy of the distribution of the national income amongst the constituent states on the basis of population appears to be the reason for manipulation of census figures. It is also part of the handiwork of political gladiators who prepare fertile grounds upon which elections can be rigged in their favor. Akinjide said of our population figures that:

That was what Lugard created in Nigeria, a permanent majority for the North. The population figure is also a fraud. In fact, a British Colonial Civil Servant who was involved in the fraud was trying to expose it but he was never allowed to publish it. The analysis is as follows: if you look at the map of West Africa, starting from Mauritania to Cameroun and take a population of each country as you move from the Coast to Savannah, the population decreases. Or conversely, as you come from the Desert to the Coast, right from Mauritania to Cameroun, the population increases. The only exception throughout the zone is Nigeria. Nigeria is the only zone whereby you go from the Coast to the North, the population increases and you come from the North to the Coast, the population decreases. ${ }^{4}$

\subsection{Over Politicization of Everything in Nigeria}

This is another major contributor to the Nigerian problem. Section 14 (1) of the 1999 Constitution regarding Federal Character has been abused that we now have a predominance of one ethnic group in charge of the security apparatus of the country where all the service chiefs are from the North, including the Minister for Defense, the Inspector General of Police, the National Security Adviser. This has led to serious suspicion and mishandling of security issues in the country. A very influential Yoruba monarch once threatened to drown Igbo residents in Lagos in the lagoon if they fail to vote for his APC preferred candidate.

\subsection{Disobedience to Court Orders}

Court orders are flagrantly disobeyed by the executive. If there is anything that the current administration of Buhari is increasingly being notorious for, it is in the manner it disregards court orders. Former National Security Adviser, Col. Sambo Dasuki (rtd), Sheikh Ibrahim

\footnotetext{
${ }^{1}$ Richard Akinjide, "The Amalgamation of Nigeria was a fraud" at https://www.m. facebook.com, Retrieved June 20, 2018, 12.37pm. Richard Akinjide (SAN) is first and second Republic Minister and delivered this address in a public presentation of the book Follow Country Men: the Story of Coup D' etats in Nigeria.

2 Ibid.(n. p.)

${ }^{3}$ S.A. Bello, Op. Cit., p. 277

${ }^{4}$ Richard Akinjide, Op. Cit., (n.p.)
} 
El-Zakzaky ${ }^{1}$ and his wife and several others have at different times secured judgments to be admitted to bail but these orders have been completely ignored. Disobedience to court order is not only a constitutional issue, ${ }^{2}$ but is a threat to democracy and a recipe for disaster. Today there are over 100 such decisions that are being disregarded, to the extent that State Governments have also taken a cue from the Federal Government in this regard. In many cases, Attorneys General have filed appeals and motions for stay of execution just to circumvent the law. It is no longer the rule of law but the rule of might notwithstanding the supreme courts unambiguous pronouncements in Oguebego v PDP, ${ }^{3}$ that any person against whom a decision of a court is given is duty bound to obey it, irrespective of whether the person against whom the order is made is of the opinion that the order is void or perverse. He is bound to obey the order until it is set aside. Self-help or disobedience to court orders by government at all levels is an attack to the rule of law, due process, can breed anarchy, dictatorship and totalitarianism which are antithesis to democracy as was held in N.B.A v Henk yaa. ${ }^{4}$ This is not as a result of any weak institution. The judiciary in these instances did their work only for the "almighty" executive to disobey and manipulate them in its favor.

\subsection{Military Incursion into Governance}

Nigeria's first military coup was not as a result of weak institution but largely for the mismanagement of our electoral processes by politicians, as well as several killings that took place then. There was the Igbo pogrom of Jos in 1945, Kano in 1953. Military rule in Nigeria first started on January 15, 1966 when a group of army officers came to correct these ills and over threw the NPC-NNDP government of Prime Minister Abubakar Tafawa Balewa. Major General Johnson Aquiyi-Ironsi was made the head of the Federal Military Government of Nigeria. This coup was unjustifiably baptized an "Igbo coup" even when the coup was quelled by Ironsi, an Igbo man. The retaliatory coup of $29^{\text {th }}$ July 1966 came, killing Ironsi and a lot of Ibo officers and civilians and enthroning the government of General Yakubu Gowon. The Igbo pogrom continued and eventually led to the Nigerian-Biafran civil war. The military having tasted power became corrupt and unwilling to relinquish power to democratic civilian government. It is noteworthy that subsequent military governments were from northern extractions ranging from major General Gowon from 30 $30^{\text {th }}$ July 1966 to July 30, 1975; Murtala Muhammed took over and was subsequently killed in the Dimka coup in 1976, and then Lt. General Olusequ Obasanjo from the south by accident became the Head of State being the most senior officer then. He handed over to the Shehu Shagari led civilian administration in 1979 who was again overthrown by the military in 1983. General Buhari became Head of State and in succession, Ibrahim Babangida, Sani Abacha, Adulsalami Abubakar, all from the north, took turns..$^{5}$ Among other reasons for military intervention in Nigeria's governance were tribal loyalty, regional differences, politicization of the army, corruption, low level of economic development, and infrastructural decay. The military also came with incompetent personnel, non-tolerance to criticism, dictatorship, a non-independent judiciary, mismanagement of public funds, violation of human rights, no respect for rule of law, corruption and the Nigerian civil war. These problems still remain with us even under a democratic government. The military has continued to recycle themselves and come back as civilian presidents like Obasanjo and Buhari has done. We do not know who will come next.

The argument here is not that there is no good side to military regimes. Military regimes that do not have much time are in unique position to conduct corrective reform and bequeath democracy. But as Max Siollun said:

...once they are in power for a prolonged time they begin to act in a more circumspect manner which robs them of the decisiveness, promptness and precision which are hall marks of a truly corrective regime. They then become sluggish and reluctant to relinquish power ... the military transferred its doctrinal attachment to regimentation, uniformity and the suppression of dissent into the political arena. It was unable to shake off its battlefield mentality and lacked the courage to terminate its own political life. The military failed in the political arena. " 6

On this score,Claude Ake added his voice when he said:

The military and democracy are in dialectical opposition. The military can never engender democracy because it is the antithesis of democracy in regard to its norms, values, purposes and structure. The military addresses the extreme and the extra-ordinary while democracy addresses the routine; the military values discipline and hierarchy; democracy freedom and equality. The military is a chain of command; democracy is a benign anarchy of diversity. Democracy presupposes human sociability; the military

\footnotetext{
${ }^{1}$ Is the leader of the Islamic Movement of Nigeria (IMN)

${ }^{2}$ See S. 287 of the Constitution of the Federal Republic of Nigeria 1999 as amended.

3 (2016) 4 NWLR (Pt 1503) p. 446 at 480 paragraph C-D

4 (2016) NWLR (Pt 1522) p. 164 at 171-172, paragraphs H-C. see also “Disobedience of court orders: Nigerian Judiciary Under Buhari's spell?" at https://www.thenigerianvoice.com, Retrieved June 21, 2018, 4.25pm

${ }^{5}$ See "History of Military Rule in Nigeria" at https://www.schoolmattazz.com, Retrieved June 23, 2018, 7.30pm.

${ }^{6}$ Max Siollun, Supra, P. 272
} 
presupposes its total absence, the inhuman extremity of killing the opposition. The military demands submission; democracy enjoins participation; one is a tool of violence, the other a means of consensus building for peaceful co-existence." I

Flowing from the above, there is no doubt that the military incursion into governance and democracy was and still is a huge mistake that has continued to relegate our practice of democracy to a level of militarism and thus affected a sustained economic and political development of the country.

\subsection{The Nigerian Civil War Philosophy}

The foundational philosophy of the Nigerian State formulated to prosecute the Nigerian Civil War has been the guiding principle of successive regimes, military and civilian alike. It is expressed in the slogan: "to keep Nigeria one is a task that must be accomplished." At some point, it was replaced with another no less barbaric slogan 'Nigeria's unity is not negotiable'. ${ }^{2}$ The respected author Chudi Offodile analyzing the events of the Nigerian civil war and its aftermath summed it beautifully this way:

'To keep Nigeria one is a task that must be done' is a dubious philosophy of genocidal origins, built on falsehood and watered with the blood of innocents. Sprouting from the ashes of Aburi, it was rightly expunged from Nigeria's political lexicon and replaced with "No victor no vanquished", in the hope of building a new nation at the end of the war in 1970. Hardliners, many of whom are still around today, ensured that this remained a mere slogan. While they publicly proclaimed it, their policies and attitudes exposed an insidious attachment to the wartime dubious philosophy. The message is coercive and cannot engender genuine patriotism, a sine qua non for meaningful development. It provided the basis and foundation for the present corrupt system. While the defeated found it abhorrent, it armed the victorious group with a sense of entitlement to pillage our collective patrimony. Soon everyone joined in the bazaar. Whilst a few top government functionaries were herded to court by the Economic and Financial Crimes Commission (EFCC), their replacements continue with business as usual, doing exactly the same things for which their predecessors were arrested. ${ }^{3}$

It must be recalled that in the historical antecedent of the Nigerian-Biafran civil war, Biafra was rated the fastest growing economy in the world. They were refining their own crude oil, manufactured war weapons including bombs, "Ogbunigwe", built bunkers, machine guns, airports etc. Today, the Nigerian government cannot refine its own crude oil. Our airports are still built by foreign engineers. We go begging countries to sell weapons to us. Chudi Offodile predicts that "Nothing will change until Nigeria finds the proper foundational matrix to galvanize the talents and resources of the Nigerian people and create a productive economy." 4 Every other pretentious adjustment will not alter the inevitable consequence of Nigeria's foundational contradictions, which is state failure. Those who have good vision of this have already started calling for restructuring or selfdetermination.

\subsection{Mono Economic Base}

Before the discovery of crude oil in Nigeria, we use to have oil palm in the Eastern Nigeria, Cocoa in the West, groundnut pyramids of the North. We produced cotton too. All were in export proportions and the economy boomed. As soon as oil was discovered, we appeared to have jettisoned other means of foreign exchange generation and concentrated on oil. In the process, we have become lazy and economic development fluctuated correspondingly with international oil prices. Our economy became solely based on easy oil money that other sectors of the economy like agriculture, tourism, technology, banking, insurance, taxation, sports, health, even prospection of other mineral deposits of which Nigeria is greatly endowed, became neglected. We lost sight of industrialization of the economy and could not even produce enough food for local consumption not to talk of exportable quantity. Policy summersaults killed our "Green Revolution" and "Operation Feed the Nation". Infrastructure decayed, and the power sector was grounded and the nation plunged into darkness. Cost of production rose to astronomical proportion and the few Nigerian products could not compete in terms of price with their foreign counterparts. Foreign exchange from oil was spent on importation of foreign consumable products. We went as low as importing tooth-picks and candles. The government said we could begin to manufacture pencil in another few years! This is laughable for a country that claims to be the biggest economy in Africa and the giant of Africa. Our dept profile has reached an all-time-high and the government is still making plans to borrow more and plunge generations yet unborn into perpetual indebtedness.

\footnotetext{
${ }^{1}$ Claude Ake, "A plausible Transition". Tell Magazine, September 25, 1995, p. 34.

${ }^{2}$ C. Offodile, The Politics of Biatra and the Future of Nigeria., (Ibadan: Satari Books Ltd 2016), p.215

${ }^{3}$ Ibid., p. 216

${ }^{4}$ Ibid.
} 


\subsection{A Faulty Constitution}

The fraud of a military imposed constitution which roguishly provides that "We the people...do hereby make and give to ourselves the following Constitution," is sickening. Our Constitution came into being by virtue of a military decree. ${ }^{1}$ It has also been argued that mere recognition that it is the people who ought to make or approve the Constitution is enough consolation given our circumstance as a nation. ${ }^{2}$ Sections 162-164 of the Constitution ${ }^{3}$ make provisions where the constituent States in Nigeria go to Abuja on monthly bases to share the federal allocation from the Federation Account. This feeding-bottle approach has made the States lazy to think of other means of generating funds for governing the State. The same applies to the Local Governments who also depend on the distribution from Federation Accounts.

There is also the issue of the concentration of all executive powers on a single person called the "President". He is the Head of State, Chief Executive of the Federation and Commander-in- Chief of the Armed Forces of the Federation. The Nigerian President is reputed to being the most powerful leader in the world by virtue of our Constitution. ${ }^{4}$ Predictably, there has been so much abuse of this power ranging from intimidation of political opponents, by trumped-up charges and detaining them without trials, to intimidation of other arms of government. We still remember the raiding of residents of Judicial officers including Supreme Court Justices in the night by the DSS (an agent of the executive), the Dino Melaye case, the former Senate President, Bukola Saraki accused of financing armed robbers, Senator Ahmed Sani Yarima docked for corruption, Senator Ike Ekwerenmadu for forgery, Senator Danjuma Goje for fraud, Senator kashamu facing threat of extradition from NDLEA, Senator Eyinnaya Abaribe is now arrested in a case where the Federal Government frustrated the attendance to court of Nnamdi Kanu whom he sureteed. The mace of the National Assembly has been stolen, with the police fingered as conspiring with the executives to intimidate the National Assembly. The IGP has refused several invitations by the National Assembly to attend her sitting for questioning. So did the Comptroller General of customs. In all these cases, Mr. President has given tacit approval by refusing to terminate their appointments. The list is endless. This is executive lawlessness and abuse of executive power. On the other hand, any corrupt government official, particularly of the executive arm who moves from his former party to the All Progressive Congress (APC), becomes an angel and untouchable by the law enforcement agents as "their sins are forgiven." See the wide powers of the President and Governors under sections 5(1) (b) and 2(b) of the 1999 Constitution.

\subsection{Weak Institutions of State}

We shall look at weak institutions from the praxes of the Nigerian Police, Army and Independent National Electoral Commission (INEC) only.

\subsection{INEC:}

One disturbing feature of elections in Nigeria which any participant or observer of election petitions will attest to is the involvement of the electoral umpire, INEC (with the help of the police and other security agents) in ensuring that any party in power gets favored in the way and manner elections are conducted. These acts ranges from thumb printing of ballot papers in favor of the ruling party, sensitive election documents are given to the agents of the ruling party; where opposition is strong, material for election will either be delayed or not supplied at all; cancellation of election results where opposition has done well; encouraging ballot box snatching and allowing exchange of money at polling booths during elections; secreting of opposition witnesses during election petitions and confirming stories of the ruling party during the trials; declaration of false results; exclusion of lawful votes from counting; falsification and forgery of result sheets; vote buying, under-aged-voting and multiple-voting are just some of the ways by which the electoral umpire rig the election in favor of any of her preferred candidates. The late President Yaradua did acknowledge that the election which brought him to power was one of the most un-free and unfair elections. In Oshiomole v Osunbor, ${ }^{5}$ a witness said he could not report the snatching of ballot boxes to the police by PDP henchmen because the then ruling party PDP and the police were like 'nut and bolt.' This is clearly a failure of INEC as an institution of State. A marred electoral process will naturally enthrone a bad government as the will of the people is subverted. When a government is foisted on the people through electoral fraud, the ultimate result is bad government, economic depression, strangulating inflation, currency devaluation, loss of lives and property, protests, insecurity and other trappings of a failed State.

\footnotetext{
${ }^{1}$ See The Constitution of the Federal Republic of Nigeria (Promulgation) Decree 1999.

2 B.O. Igwenyi, Modern Constitutional Law in Nigeria, $2^{\text {nd }}$ Edition (Abakaliki: Nwamazi Printing \& Publication co. Ltd., 2010) p. 12.

${ }^{3}$ The constitution of Nigeria 1999 as amended.

${ }^{4}$ Ibid., S. 130

5 (2008) 48 WRN 24

${ }^{6}$ G.C. Ihenetu, The Nigerian Law Students'Journal (Lagos: De Quintessence; maiden edition 2010), (n.v), P. 73; see also Abiodun Odusote, "Nigerian and Electoral Process Since Amalgamation: Lessons from a Turbulent Past," Proceeding of the 47 Annual conference of the Nigerian Association of Law Teachers (NALT) (ed. C.A. Omaka , 2014)(n.v.) pp. 172-196.
} 


\subsection{The Police}

Whilst the 1963 and 1979 Constitution of Nigeria did not provide for the functions of the Nigerian Police Force directly but left it to the parliament to organize, the 1958 Police Act provided for the functions of the Police. The Police Act Cap 359 of 1990 amended the 1958 Act by substituting the word "Governor-General" with "this or any other Act" it provides that;

The police shall be employed for the prevention and detection of crime, the apprehension of offenders, the preservation of law and order, the protection of property and the due enforcement of all laws and regulations with which they are directly charged and shall perform such military duties within or without Nigeria as may be required of them by, or under the authority of this or any other Act."

There is no gainsaying the fact that the Nigerian Police has not lived up to these mandates in very many respects. The Nigerian Police is reactive rather than proactive. It tries to detect crime after it has been committed, and have had little success in this respect, while it has done practically nothing in trying to prevent crimes. Sometimes, the police gets directly involved in the commission of crimes it is supposed to prevent. We all remember the "Apo Six" where the police killed 6 youths on very suspicious circumstances. There is the recent killing of a Youth Corp member by the police. The dailies are replete with many incidents of accidental discharge from police gun resulting in death of innocent citizens. When armed robbers are caught, they are "wasted" before they can be tried. Police has helped in election rigging in the country. Some of them are accomplices to cases of kidnapping, robbery, rape and other vicious crimes. They have become instrument of intimidation in the hands of successive ruling parties. Their next name is corruption as police check points are duty posts of extortion and intimidation. There have been cries by the Nigerian public for the scrapping of SARS. The activities of the likes of Tafa Balogun, a former Inspector General of Police, are still fresh in our memories. Human rights abuses have become the rule rather than the exception. There is serious capacity failure within the police. These failures in some cases are hardly the fault of the police force itself. There is inadequate funding and provision of modern gadgets to combat crime. It has been revealed that about $80 \%$ of officers of the Nigerian Police Force are assigned to secure VIPs rather than the general public. Nigeria's effective police officer to population ratio is I (one) to 2,514. ${ }^{1}$ This ranks among the lowest police-population ratios in the world. This has negatively affected the police ability to detect, prevent, monitor and investigate crime. Every now and then you hear police admitting to being overwhelmed by armed bandits, herdsmen, Boko Haram. It must be stated that there are many police officers who are upright, diligent, honest and effective in their work in spite of the very poor funding of the police. The conclusion however, is that the police is a failed institution of state unfortunately. Recently a report released by the National Bureau of Statistics (NBS) and the United Nations Office of Drugs and Crime (UNODC) rated the police as the most corrupt institution in Nigeria. ${ }^{2}$ I would like to stop so far on the Nigerian Police for want of space.

\subsection{The Nigerian Army}

I have already dealt with the disruptive influences of the Nigerian army in our quest for a sustainable democracy, the military's love for power and the consequent corruption into which it became submerged. Apart from her failure to finally defeat the Boko Haram and the recent accusations against it of having taken side with the "Fulani herdsmen" in the Benue State killings and destruction of properties, one can safely say that everything put together, the Nigerian military has not totally failed as an institution of state. This is particularly true when we judge them from the point of view of their primary function, which is the responsibility of defending the territorial integrity of Nigeria. They have fought a civil war and kept Nigeria as one. No other nation has successfully invaded and taken away any territory of Nigeria. The military has been engaged in peace keeping operations in other African countries and have kept a good record of success. In fact the Nigerian military is rated one of the best in Africa. The failure to completely tackle and defeat the Boko Haram stems from inadequate funding of their operations and lack of motivation for the officers. It is a fact that they have fought this war with inferior weapons compared to what the insurgents have. Col Sambo Dasuki is still standing trial for diversion of money meant for purchase of modern war equipments for the military. It is on record that at one point, young officers were said to have mutinied and refused to confront the Boko Haram with their "bare hands" as was the claim. Notwithstanding this fact, the boys were made to face trial and were sentenced to prison terms with some dismissed from the army. This speaks of the high level of discipline that still subsists within the military set up. Again we must not lose sight of the fact that the Boko Haram is an unconventional war where the enemy is not easily identified and cowardly choose to attack soft targets of civilian residents and clusters. The military incursion into governance would not depict weakness but strength. It is also true that anytime the police is overwhelmed by any situation, it is still the Nigerian military that has been invited to take care of such situation. The Nigerian army has been voted as the best institution

\footnotetext{
${ }^{1}$ This was a revelation by Assistant Inspector General of Police Zone 5, Mr. Rasheed AKintunde. See T. Lawal, "Capacity Failure of the Police: Privatization as a Solution." at https://www.thecable.ng, Retrieved June 23, 2018. 5.30pm

2 See "NBS Report about Corruption in Police Misleading Say Police" at https://www.thisdaylive.com Retrieved June 23, 2018. 5.35pm.
} 
of the month ${ }^{1}$. This cannot be for doing nothing.

\subsection{Recommendations}

This paper recommends that it is safer to say that weak institutions of state has contributed to the problems of Nigeria but cannot be said to be mainly anchored upon it, otherwise, we will be leaving the substance and pursuing the shadows. The identified Nigerian problems have simple solutions.

\subsection{Amalgamation}

There is a lesson we can learn from Catalonia, Flanders and even Scotland. In Scotland, residents will have to decide on whether their homeland should become an independent country or remain part of the United Kingdom. Also in Catalonia, Spain Provincial President, Arthur Mas has called for a referendum on whether Catalonia should become a sovereign state. And in the Belgian province of Flanders, the leader of the ruling party has called for negotiations that would "enable both Flanders and French-speaking Wallonia to look after their own affair." All these secession plans are without any form of violence but are being peacefully expressed within the context of their various constitutions. Nigeria should do the same and allow for a referendum to decide whether component parts still want to remain in Nigeria or go their separate ways. They can now develop at their own pace. Alternatively, the government should heed the call for genuine restructuring. This will allow the component States to develop at their pace and douse the call for self-determination.

\subsection{Restructuring}

We must embark on a holistic restructuring of the Nigerian nation and allow true federalism where component States own their natural resources and contribute to the federation account rather than the unitary-federalism we now practice.

\subsection{Police}

Regions or the Geo-political Zones or States should be allowed to own and fund their own police. That way, those who know the geography of the communities and the residents, are employed and detection and prevention of crime becomes easy. Even police corruption will disappear as members of the community also know members of the police force within their locality, and can easily report when they start living above their means. Adequate funding and training should also be given to them to avoid abuse of their powers. Special police unit can be created for the enforcement of court orders whether it is against government or not.

\subsection{Census}

A clear and sincere census should be conducted without any political influence. A census commission that is independent and that is funded directly from the Federation Account can be created to update the figures every 2 or 4 years. A digitized national identification card which will be compulsory and serialized for all citizens should be adopted. Banks, schools, hospitals and indeed all government agencies should be mandated not to attend to any person without a national ID card. This way, we can have an accurate figure of our population upon which a meaningful development plan can be based.

\subsection{Post War Philosophy}

We should abandon this approach of "Nigeria's unity is not negotiable". "No victor, no vanquished" should be made to manifest in the government policies in an honest and just manner that will win back the trust of the Igbos and other ethnic nationalities. Those economic areas where they have very high relative advantage should be funded by the Federal Government and be allowed to flourish and blossom. Equity should be ensured in appointments into government positions, and they should be allowed to occupy the highest position in the landthe presidency. IPOB, MOSSOB etc will die a natural death if they have this sense of belonging. Those who kill and destroy their properties should be made to face the law.

\subsection{Mono Economy}

Nigeria should as a matter of urgency diversify her economic base to maximize the potentials of our human and material resources and vast land. What is required is a focused and well thought out economic plan that will have over $80 \%$ technology based technique that will sprout industrialization and bring us into the advancement of the next century globally.

\subsection{INEC}

The Independent National Electoral Commission should be made to be truly independent. The prosecution of

\footnotetext{
${ }^{1}$ See “why Nigerians Voted Nigerian Army as Best Institution of the Month”, at https://www.vanguardngr.com Retrieved June 25, 2018, 9.30am.
} 
electoral offenders should be televised and special courts assigned with electoral matters. A highly organized penal regime should be put in place to deter electoral offenders. Staff of the commission should be well remunerated and their funding should not be tied to the whims and caprices of the ruling party. This will make them truly independent of "favors" from government in power and well positioned as impartial umpires of our electoral processes.

It is my belief that if these recommendations are sincerely pursued, most of Nigeria's problems will be a thing of the past or at least reduced to the barest minimum.

\subsection{Conclusion}

Whilst it is true to say that weak institutions have contributed to Nigeria's problems, it will not be true to say that they are mainly responsible for our problems. It is our sincere submission that even if institutions of State are made strong, the very obvious differences in culture, religion, traditions, values, the amalgamation issues, the military incursion which is even evidence of a strong institution, the mono-economic base, will still create intractable problems of their own. These other factors appear to have contributed more to our problems than weak institutions of State.

\section{References}

Ake Claude,(1995). A Plausible Transition. Tell Magazine, September 25

Akinjide, R, The Amalgamation of Nigeria was a Fraud. [Online] Available: https://www.m.facebook.com.

Akinnda Richard, Fellow Countrymen: The story of Coup D'états in Nigeria. [Online] Available: https://www.premiumtimesng.com $>$ tag

Baker, R.,(1999). Money Laundering and Flight Capital: The Impact in Private Banking. Senate Committee on Governmental Affairs Permanent Subcommittee on Investigation Report November 10, 1999

Bello, S.A, (2015). The Nigerian State and the Challenge of Divisionism and Dichotomy. Journal of Contemporary Legal and Allied Issues, Ife Juris Law Review, part

Boko Haram Released Video of Chibok Girls. [Online] Available: https://www.telegraph.co.uk>bokoharam

Dapchi Girls Kidnapp, Release was Staged to Swindle Nigerians. [Online] Available: https://www.saharareporters.com>2018/03/21>dapchi

Dapchi Schoolgrils Kidnapping-Wikipedia. [Online] Available: https://en.m.wikipedia.org >wiki>Dapchi

Disobedience of Court Orders: Nigerian Judiciary Under Buhari's Spell? [Online] Available: https://www.thenigerianvoice.com

Economic and Financial Crimes Commission Act 2004

Elombah, D, Olusegun Obasanjo Versus Ndudi Elumelu. [Online] Available: https://www.elombah.com/index.php?option=com-content\&view $=$ article $\&$ id $=803$ : Olusequn-Obasanjoversus-godwin-elumelu\&cat id=52: Daniel - elombah\& Itemid=73

English Dictionary. [Online] Available: https://www.dictionary.com

Failed State Index (2009) [Online] Available: https://www.proshareng.com

Fresh Blood bath in Benue, 2 Catholic Priest, 17 others killed by Herdsmen. [Online] Available: https://www.vanquard.com/2018/04/fresh-blood

Garner, B.A, (Editor-in-chief), (2004), Black's Law Dictionary $8^{\text {th }}$ ed. (US: Thomson West)

Girling, J,(1997). Corruption, Capitalism and Democracy. London: Rout ledge

Henning, P.J, (2001). Public Corruption: A Comparative Analysis of International Corruption Conventions and United States Law. Arizona Journal of International and Comparative Law, Vol. 18 (n.n.)

History of Military Rule in Nigeria. [Online] Available: https://www.schoolmattazz.com

Igbinedion, S.A, (2013). Enthroning Good Governance in Nigeria: The Challenge of Corruption. A Journal of Contemporary Legal Issues, Vol. 5

Igwenyi, B.O, (2010). Modern Constitutional Law in Nigeria (Abakaliki: Nwamazi Printing \& Publication Co. Ltd, $2^{\text {nd }}$ Edition

Ihenetu, G.C, (2010). The Nigerian Law Students' Journal (Lagos: De Quintessence, Maiden edition

Lawal, T, Capacity Failure of the Police: Privatization as a Solution. [Online] Available: https://www.thecable.ng Masland, T. et al, (2000). The Lost Billions: The Inside Story of the Hunt-From Lagos to New York to Geneva For an African Dictator's Stolen Loot, Newsweek March 13

Michelle Obama's \# Bring Back Our Girls Picture Sparks Criticism of American Drone Strikes. [Online] Available: https://www.washingtonpost.com > news

Nigeria’s Dauski Arrested Over $\$ 2$ billion Arms Fraud. [Online] Available: https:/www.bbc.com>w

Obi Paul, NBS Report About Corruption in Police Misleading Say Police. [Online] Available: https://www.thisdaylive.com

Odusote Abiodun, (2014). Nigerian and Electoral Process Since Amalgamation: Lessons from a Turbulent Past. Proceedings of the $47^{\text {th }}$ Annual Conference of the Nigeria Association of Law Teachers (NALT) ed. Omaka 
C.A

Offodile, C, (2016). The Politics of Biafra and the Future of Nigeria. Ibadan: Safari Books Ltd

Oguebego v PDP (2016) 4 NWLR pt.1503

Okigbo, P, (1994). Panel on the Reorganization and Reform of the Central Bank of Nigeria Report, Executive Summary. [Online] Available: https://dawodu.com/okigboreport/htm

Opinion: Is 1914 Amalgamation a Blessing or a Curse? [Online] Available: https://www.thewillnigeria.com

Oshiomole v Osunbor (2008) 48 WRN

Our prayers are with the Missing Nigerian Girls and their Families. [Online] Available:https://www.twitter.com $>$ flotus $44>$ status

Reps Cry Foul Over use of $\$ 270 \mathrm{~m}$. to clear Grass at IDP Camps-Vanguard News [Online] Available: https://www.vanguard.com

Senate Joint Committee on Public Service and Establishment and States and Local Government Administration Report. [Online] Available: https://www.allafrica.com/stories/201206210904. html

Shihata, I.F.I, (1997). Corruption-A General Review with an Emphasis on the Role of the World Bank. Dickinson Journal of International Law, Vol. 15

Siollun Max, (2013). Soldiers of Fortune, Nigerian Politics From Buhari to Babangida 1983-1993. Abuja: Nigeria Cassava Republic Press, Appendix 1.

The Constitution of the Federal Republic of Nigeria (Promulgation) Decree 1999.

The Constitution of the Federal republic of Nigeria 1999 as amended

To verify and Determine the Actual subsidy requirements and Monitor the Implementation of the subsidy Regime in Nigeria Resolution No. HR.1/2012. [Online] Available: https: //www.nigerianmuse.com/wpcontent/uploads/2012/04/House-pdf

Transparency International, Survey and Indices. [Online] Available: https://www.archive.transparency.org/policy_research/surveys_indices/cpi

Trump Warns Buhari Over killing of Christians in Nigeria. [Online] Available: https://www.google.com.ng

Wehmeier ally, Ashby M. ed. (2000). Oxford Advanced Learners Dictionary of Current English. New York: Oxford University Press

Why Nigerians Voted Nigerian Army as best Institution of the month. [Online] Available: https://www.vanguardnge.com

\section{THIS ARTICLE IS BY:}

Arthur Elvis Chukwu

Senior Lecturer, Head of Department Professional Ethics \& Skills

Nigerian Law School. 